\title{
Hawking Irreversibility and Socio-Economic Determinism
}

\author{
Jan-Erik Lane \\ Fellow with Public Policy Institute, Belgrade; Address: 10 Charles Humbert, 1205 \\ Geneva; 559 A, 3rd Floor, Thuya Street, 9th Quarter, Yangon, Myanmar
}

Florent Dieterlen

Independent scholar, Geneva

Received: September 22, 2017 Accepted: December 30, 2017 Published: January 2, 2018

doi: 10.5296/jsss.v5i1.12394

URL: http://doi.org/10.5296/jsss.v5i1.12394

\begin{abstract}
Physicist Stephen Hawking has suggested that climate changes is about to become unstoppable. One may introduce a concept of Hawking irreversibility as the point where temperature has risen so much that the global warming consequences threaten the survival of mankind. The recent news out of China that its $\mathrm{CO} 2 \mathrm{~s}$ are increasing again makes this term highly policy relevant. Moreover, the methane emissions have started to augment, which also calls up Hawking irreversibility. The drive behind these dire developments is the endless zest for affluence and wealth, fueled by ever larger energy consumption.
\end{abstract}

Kewwords: Decarbonisation, Hawking irreversibility, GHCs, CO2S, Methane, COP21 Treaty goals, Solar power plants

\section{INTRODUCTION}

Climate scientists warn, already before the implementation of the UNFCCC Agreement from Paris 2015 that the decarbonisation plan decided in global governance will not be enough to stabilize temperature at +2 Celsius, at most. Global average temperature will most probably be larger than the COP21 objective. At what point on the temperature scale, we move into Hawking irreversibility is not known. But a rise beyond +4 degrees will have dramatic consequences for the ecology and human social systems.

A few days before the start of the UN global environment reunion COP23 (6-13 November 2017) in Bonn, the major study Climate Science Special Report: Fourth National Climate Assessment (USGCRP, 2017): was published in Washington. It examines the global warming 
problematic from the point of view of the US and the world, based upon years of research by a large group of US scholars. It definitively recommends a combination of national and international policy-making to halt temperature rise, despite the fact that the US government is negative. It renders an impressive list of climate change impacts upon the US territory and points decisively at human causes. We must then ask: Can decarbonisation policies be implemented or managed? The COP23 by the UNFCCC reflects upon the very same problem.

If or when global warming reaches the point of no return with temperatures perhaps plus 4-6 degrees Celsius higher, then the present calamities will be magnified : a) Melting of polar ice massively: b) Retraction of glaciers globally; c) Huge land losses along the costs (Bangladesh); d) Too high temperatures for men and women to work outside (South Asia); e) Food production decline (Africa); f) Fish harvest decrease (Atlantic ocean, Pacific Ocean); g) Droughts and starvation (South Asia); h) Lack of fresh water supply (Latin America); i0 Drying up of rivers, affecting electricity supply (Latin America, South Asia, East Asia); j) Ocean acidification and species extinction (Australia); k) Highly volatile climate with giant forest fires, storms, rainfall and tornados with tremendous damages inclusing mudslides(Caribbean, North America, Sri Lanka, Vietnam, China, Australia)); 1) Deforestation and desertification (Latin America, Africa, Indonesia, South Asia).. If worse comes to worse, global heat streams like the Gulf Stream and the Atlantic Current may be affected, changing weather in the Northern and Southern hemispheres.

\section{Present Global Predicament}

\section{a) No Kuznets' curve for CO2s}

The greenhouse gases (GHG) have a strong anthropogenic sources, being linked with socio-economic development or economic growth via the consumption of energy, especially the burning of fossil fuels, use of cement and emission of methane from landsinks, cows, microbes, etc. The UNFCCC has focused on halting $\mathrm{CO} 2 \mathrm{~s}$ and decreasing them in a gigantic decarbonisation policy globally in this century. Figure 1shows that there is no Kuznets' curve (first rising, then descending) for $\mathrm{CO} 2$ : richer countries emit more $\mathrm{CO} 2$ than poor ones. International aviation is a very major source of $\mathrm{CO} 2$ emissions, and it is booming.

GDP - CO2 emissions World countries 2016
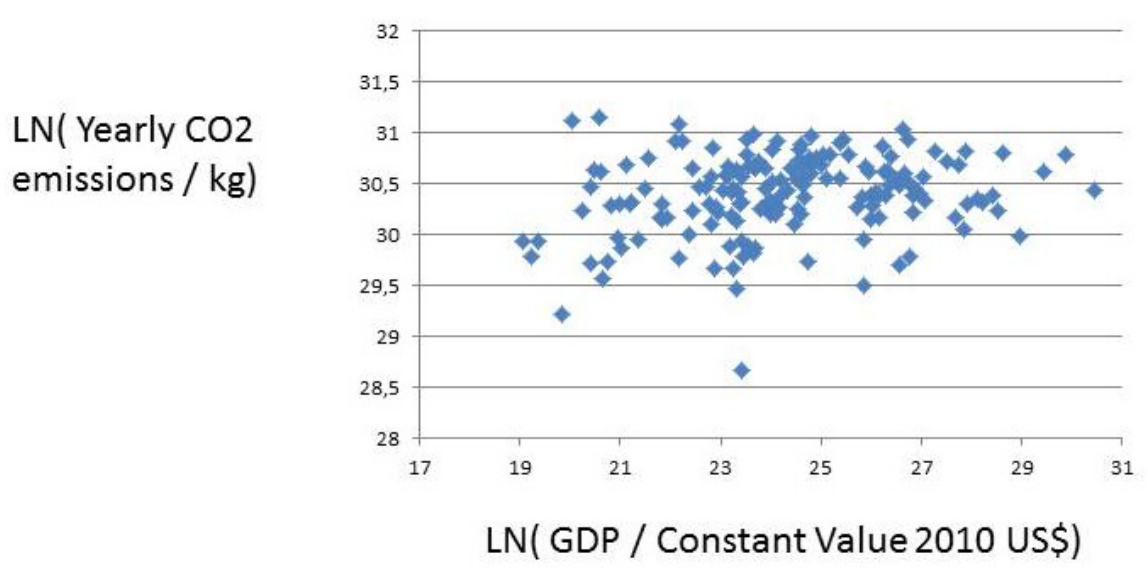
Figure 1. GDP-COP for all countries

Source:

All countries in the world have formed a common pool regime (CPR) to save the atmosphere from more GHGs, focusing only upon the $\mathrm{CO} 2 \mathrm{~s}$. The global decarbonisation plan includes:

i) Halting the rise if CO2s by 2020 (GOAL I);

ii) Reducing the CO2s by $30-40 \%$ by 2030 (GOAL II);

iii) Complete decarbonisation by around 2075 (GOAL III);

iv) Decentralised implementation under international oversight, financial support and technical assistance.

These are enormous goals, as only one country - Uruguay - is near GOAL I and GOAL II. Some countries have lately had stalling or even decreasing $\mathrm{CO} 2 \mathrm{~s}$, but many other still face an upward sloping curve.

\section{b) Energy}

Energy generates not only survival but also affluence and wealth, being vital to both poor and rich countries. If energy consumption is reduced, there will be global economic recessions and mass poverty as well as unemployment. But Planet Earth consumes too much energy from one major source: burning fossil fuels. One may employ some standard sources on energy consumption and what is immediately obvious is the immensely huge numbers involved - see Table 1.

Table 1. Energy consumption 2015 (Million Tons of oil equivalent)

\begin{tabular}{ccc}
\hline & Total & $\%$ \\
\hline Fossil fuels & 11306.4 & 86.0 \\
Oil & 4331.3 & 32.9 \\
Natural Gas & 3135.2 & 23.8 \\
Coal & 3839.9 & 29.2 \\
Renewables & 1257.8 & 9.6 \\
Hydroelectric & 892.9 & 6.8 \\
Others & 364.9 & 2.8 \\
Nuclear power & 583.1 & 4.4 \\
Total & 13147.3 & 100.0 \\
\hline
\end{tabular}

Source: BP Statistical Review of World Energy 2016.

Table 1 holds the answer to why GHG emissions have become the global headache number 1 . Energy for humans and their social systems come to an average of $90 \%$ from burning fossil fuels: stone and wood coal, oil and gas. And people do that all over the world, though to very different degrees from $100 \%$ to less than $50 \%$ of all energy consumption, because it is necessary for affluence and survival. The enormous expansion in the energy consumption of fossil fuels has allowed the world to take on many new inhabitants, as well as reducing poverty in the Third World and much enhancing affluence and wealth in the First world. 


\section{Macrothink}

CO2 emissions are closely connected with energy consumption, globally speaking. Projections for future energy augmentation in the 21st century are enormous, especially for Asia (EIA, BP, IEA). Figure 2 developments since 1990.

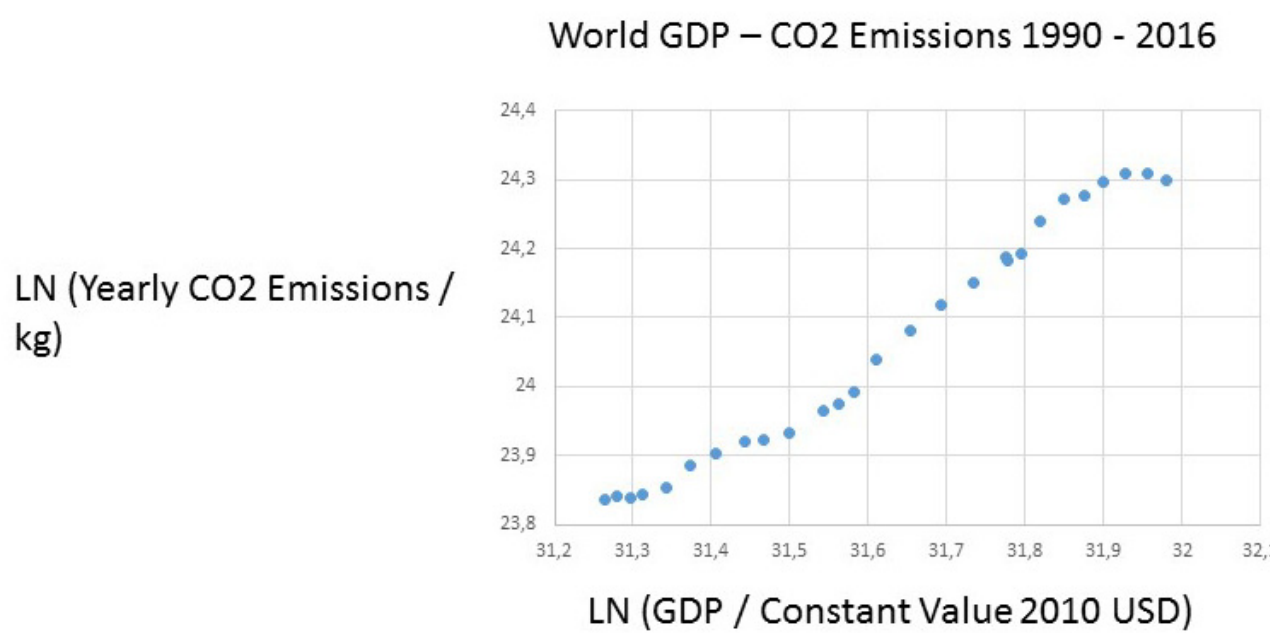

Figure 2. Global GDP-CO2 link: $\mathrm{y}=0.7498 \mathrm{x}, \mathrm{R}^{2}=0.9801$

GDP increases with the augmentation of energy per capita. Decarbonisation is the promise to undo these dismal links by making GDP and energy consumption rely upon carbon neutral energy resources, like modern renewables and atomic energy.

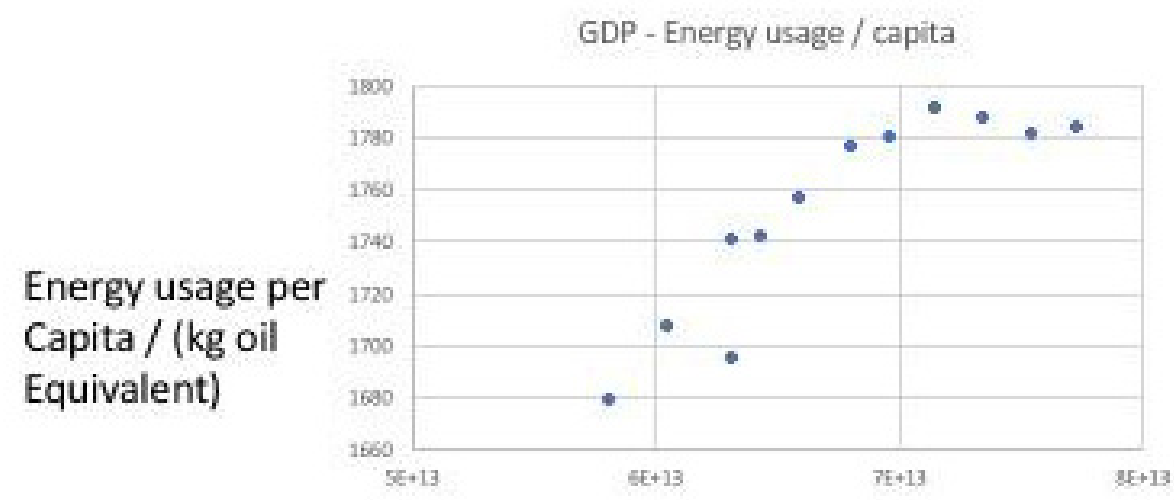

GDP / (Constant value 2010 USD)

Figure 3. GDP against energy per person, 2005-2016

Source: World Bank Data Indicators, data.worldbank.org; BP Statistical Review of World Energy 2017

Both curves in Figures 2 and 3 indicate stalling, which is what the UNFCCC hopes for. But recent new out of China informs about renewed augmentation of CO2s in 2017. Together with recent trends in methane emissions, Hawking irreversibility is not far off. 


\section{Temperature Rise}

\section{a) $\mathrm{CO} 2 \mathrm{~s}$}

One may attempt to calculate exactly how increases in greenhouse gases impact upon temperature augmentations. Take the case of $\mathrm{CO} 2 \mathrm{~s}$, where a most complicated mathematical formula is employed: $\mathrm{T}=\mathrm{Tc}+\mathrm{Tn}$, where $\mathrm{T}$ is temperature, $\mathrm{Tc}$ is the cumulative net contribution to temperature from $\mathrm{CO} 2$ and $\mathrm{Tn}$ the normal temperature. Moreover, the general formula reads: $\mathrm{dT}=\lambda^{*} \mathrm{dF}$, where ' $\mathrm{dT}$ ' is the change in the Earth's average surface temperature, ' $\lambda$ ' is the climate sensitivity, usually with degrees Celsius per Watts per square meter $\left({ }^{\circ} \mathrm{C} /[\mathrm{W} / \mathrm{m} 2]\right)$, and ' $\mathrm{dF}$ ' is the radiative forcing. To get the calculations going, we start from lambda between 0.54 and 1.2 , but let's take the average $=0.87$. Thus, we have the formula (Myhre el al., 1998): Formula:

$$
0.87 \times 5.35 \times \ln (\mathrm{C} / 280) .
$$

Figure 4 shows how $\mathrm{CO} 2$ emissions may raise temperature to 4-5 degrees, which would be Hawking's worst case scenario.

\section{CO2 atmospheric concentration vs. Rise in global temperature}

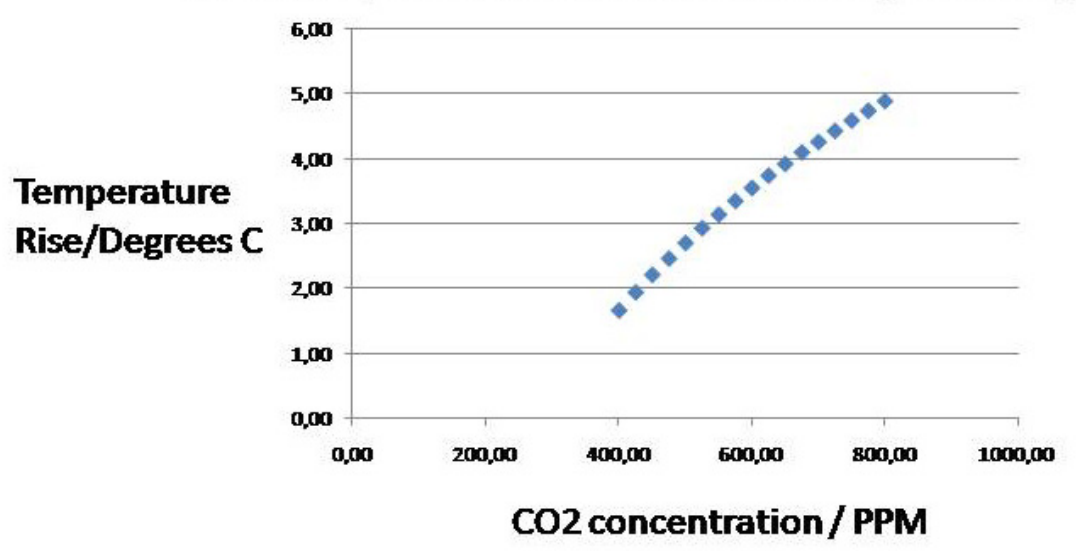

Figure 4. $\mathrm{CO} 2 \mathrm{~s}$ and temperature rise in Celsius

No one knows where the critical temperature rise occurs, i.e. from which Celsius degree global warming becomes "irreversible", to use Stephen Hawking's expression. It could be as low as +2 Celsius or as high as +5 Celsius.

There are several greenhouse gases, but the two biggest are the $\mathrm{CO} 2 \mathrm{~s}$ and methane. The UNFCCC has concentrated upon halting and reducing carbon dioxide, but now we are about to face a methane threat. Moving now and up to 2030, according to the COP21's GOAL II for decarbonisation would eliminate Hawking irreversibility Time has come for halting and reducing $\mathrm{CO} 2$ emissions by real implementation and not utopian dreams of a sustainable economy (Sachs, 2015). There is nothing to wait for any longer (Stern, 2015), as the COP23 must set up the promised Super Fund. No time for politicking in the UN any longer (Conca, 2015; Vogler, 2016). Yet, could socio-economic determinism drive mankind to take proper action according to the COP21 Treaty? 


\section{Macrothink}

\section{b) Methane emissions}

We shall use the methane concentration curve from mid 2013 to beginning of 2017 issued by NOAA ESRL https://www.esrl.noaa.gov/gmd/ccgg/trends_ch4/, gently suggested by Dlugokencky and Kuniyuki. Why mid 2013? Because it is the last maximum of the second derivative before 2017. Since then, the curve is approximately linear, and we will derive its equation hereunder.

Why should we start with a linear approximation, the simplest approximation that can be found? Because it is a mean between two extreme scenarios:

1) Another plateau like during the years 1999-2006 (probably due to an enhancement in methane transport insulation in ex-USSR after 1991, Pearce), unlikely for the following reasons. Any decrease in methane concentration is very unlikely, as the main sources (in decreasing importance order) generally increase:

a) Agriculture emissions increase with the increase of population, the increase in meat diet in developing countries and the temperature increasing the metabolism of microbes in rice agriculture.

b) Wetlands emissions don't diminish yet, as the microbial chemical activity will increase with temperature for many years.

c) Fossil fuel production and use doesn't diminish yet, and was underestimated by industry (Fred

Pearce, http://e360.yale.edu/features/methane_riddle_what_is_causing_the_rise_in_emissions ).

d) Biomass burning doesn't diminish yet, therefore the primary forest diminishes in the tropics, leading also to a decrease in animal, vegetal and cultural (Indigenous People) diversities and an increase in biosphere entropy.

e) Other natural emissions

The most important contribution to the recent rise of methane concentration is mainly due to the increase in activity by microbes, present in points a), b) and d) (Nisbet, in the above reference), mainly in the tropics. This study suggests the positive feedback of the chemical increase of activity of microbes is starting now, yielding a quasi-exponential curve in the near future, or at least a steeper curve.

We will derive examples of future increase in methane concentration due to such a positive feedback, in addition to a linear approximation. For this, we will not simulate differential equations, which would be the best option, but simulate the hypothetical solution of a transition (bifurcation) between 2 steady-states, with a S-shaped function (which approximate the bifurcation between 2 steady-states) multiplied (to have continuity) by the linear approximation. We shall approximate the S-shape curve by an transitory (5 years) exponential curve in continuity with the linear approximation.

The present (November 2017) quasi-linear curve starts mid 2013 (2013.5) and its ordinate is approximately $1813 \mathrm{ppb}$. We will use as a last value at start of 2017 (2017), and the function is approximately $1846 \mathrm{ppb}$. a straightforward calculation gives the slope: it is approximately 10 $\mathrm{ppb} / \mathrm{year}$. Therefore the equation for the future curve if there is no vicious circle (positive feedback) is: 


$$
\mathrm{y}=10(\mathrm{t}-2013.5)+1813
$$

where $\mathrm{t}$ is the time when one wants to know the $\mathrm{CH}_{4}$ concentration, and $\mathrm{y}$ is the future $\mathrm{CH}_{4}$ concentration in ppb. From this equation, one can estimate the approximate the temperature rise due by methane, by applying to y the formula (1), and multiply it by 25 . It will be valid for close future, but will probably be underestimated for farther future, where it will probably closer to an exponential.

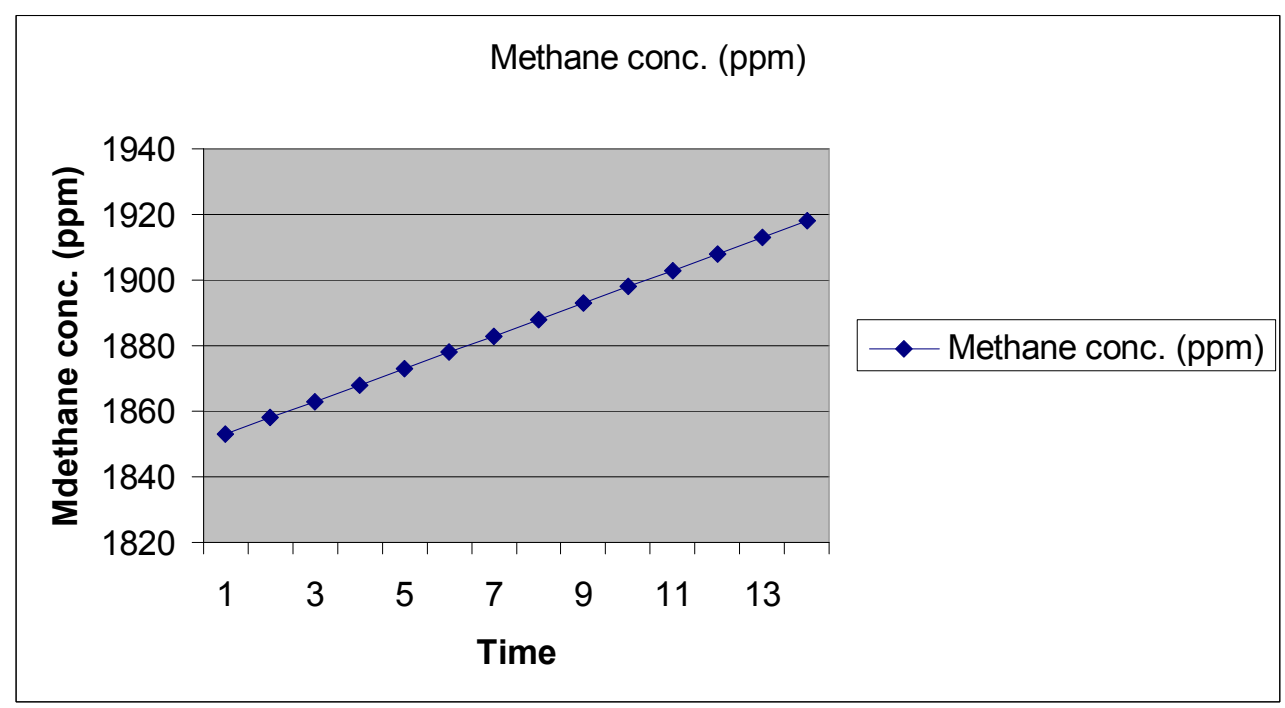

Diagram 1. Projected increase in methane

\section{Decarbonisation Srategies}

The UNFCCC suggests a decentralized management strategy for decarbonisation. Reflecting the enormous differences in available energy resources in the member states of COP21 Treaty, each government must develop a strategy for achieving Goal I, Goal II and Goal III. The COP may wish to concentrate upon the following measures start credible decarbonisation:

1) Phasing out coal power plants; convincing a few countries like India and Australia not to build new ones;

2) Replace wood coal with natural gas - small or large scale, stopping deforestation and the use of charcoal in households in poor nations;

3) Massive construction of solar power and wind power plants in all countries, as well as stimulate small scale solar power;

4) Turn some countries away from massive dam constructions towards solar power parks, like Brazil and India, as the environmental damages are too big;

5) Help some countries maintain their huge forests;

6) Abstain from expensive and unsafe carbon sequestration techniques in favour of electricity: solar power and electrical vehicles.

7) The promise of financial support - Super Fund -has to be clarified about both funding and budgeting. A management structure has to be introduced for oversight of the entire 


\section{Macrothink}

Journal of Social Science Studies

ISSN 2329-9150 2018, Vol. 5, No. 1

decarbonisation process. As the emission of methane increases, the reduction of $\mathrm{CO} 2 \mathrm{~s}$ is all the more important, if irreversibility is to be avoided with a margin.

The resort to atomic power plants is highly contested. Nuclear power gets safer and safer, but the problem of storing the used uranium has no solution. If global warming becomes really bad, all these radioactive materials could be released back in our social systems and nature. Some countries expand atomic energy, whereas others dismantle it.

\section{Solarpower Parks - A Model Example}

Consider now Table 3, using the giant solar power station in Morocco as the benchmark How many would be needed to replace the energy cut in fossil fuels and maintain the same energy amount, for a few selected countries with big CO2 emissions?

Table 2. Number of Ouarzazate plants necessary in 2030 for COP21's GOAL II: (Note: Average of 250 - 300 days of sunshine used for all entries except Australia, Indonesia, and Mexico, where 300 - 350 was used)

\begin{tabular}{|c|c|c|c|}
\hline Nation & $\begin{array}{l}\text { Co2 reduction } \\
\text { pledge / } \\
\% \text { of } 2005 \text { emissions }\end{array}$ & $\begin{array}{l}\text { Number of gigantic } \\
\text { solar plants needed } \\
\text { (Ouarzazate) }\end{array}$ & $\begin{array}{l}\text { Gigantic plants } \\
\text { needed for } 40 \% \\
\text { reduction }\end{array}$ \\
\hline United States & $26-28^{\mathrm{i}}$ & 2100 & 3200 \\
\hline China & None $^{\mathrm{ii}}$ & 0 & 3300 \\
\hline EU28 & $41-42$ & 2300 & 2300 \\
\hline India & None $^{\mathrm{ii}}$ & 0 & 600 \\
\hline Japan & 26 & 460 & 700 \\
\hline Brazil & 43 & 180 & 170 \\
\hline Indonesia & 29 & 120 & 170 \\
\hline Canada & 30 & 230 & 300 \\
\hline Mexico & 25 & 120 & 200 \\
\hline Australia & $26-28$ & 130 & 190 \\
\hline Russia & None $^{\mathrm{iii}}$ & 0 & 940 \\
\hline Canada & 30 & 230 & 300 \\
\hline
\end{tabular}




\begin{tabular}{llcc}
\hline Mexico & 25 & 120 & 200 \\
France & $37^{\mathrm{v}}$ & 210 & 220 \\
Italy & $35^{\mathrm{v}}$ & 230 & 270 \\
Sweden & $42^{\mathrm{v}}$ & 30 & 30 \\
Argentina & None ${ }^{\mathrm{ii}}$ & 0 & 80 \\
Uruguay & None $\mathrm{ei}^{\mathrm{ii}}$ & 0 & 3 \\
Chile & 35 & 25 & 30 \\
World & N/A & N/A & 16000 \\
\hline
\end{tabular}

Notes:

1) The United States has pulled out of the deal; 2) No absolute target; 3) Pledge is above current level, no reduction; 4) Upper limit dependent on receiving financial support; 5) EU joint pledge of $40 \%$ compared to 1990

If countries rely much upon water or geo-thermal power or atomic power, the number in Table 2 will be reduced. Table 2 displays the dependency upon fossil fuels that may go over $90 \%$ in some countries. Each country energy predicament is both situation dependent and path dependent, reflecting natural resources and past policies/

The key question is: Can so much solar power be constructed in some 10 years? If not, Hawking may be right. Thus, the COP23 should decide to embark upon an energy transformation of this colossal size.

Solar power investments will have to take many things into account: energy mix, climate, access to land, energy storage facilities, etc. They are preferable to nuclear power, which pushes the pollution problem into the distant future with other kinds of dangers. Geo-thermal power comes from volcanic power and sites.

It has been researched has much a climate of Canadian type impacts upon solar power efficiency. In any case, Canada will need back-ups for its many solar power parks, like gas power stations. Mexico has a very favourable situation for solar power, but will need financing from the Super Fund, promised in COP21 Treaty. In Latin America, solar power is the future, especially as water shortages from the Andes may be expected. Chile can manage their quota, but Argentine needs the Super Fund for sure. Uruguay has the best number globally, relying upon water and biomass.

Table 3 has the data for the African and Asian scene with a few key countries, poor or medium income. 
Table 3. Number of Ouarzazate plants necessary in 2030 for COP21's GOAL II: (Note: Average of 300 - 350 days of sunshine per year was used).

\begin{tabular}{|c|c|c|c|}
\hline Nation & $\begin{array}{l}\text { Co2 reduction } \\
\text { pledge / } \\
\% \text { of } 2005 \text { emissions }\end{array}$ & $\begin{array}{l}\text { Number of gigantic } \\
\text { solar plants needed } \\
\text { (Ouarzazate) }\end{array}$ & $\begin{array}{l}\text { Gigantic } \quad \text { plants } \\
\text { needed for } 40 \% \\
\text { reduction }\end{array}$ \\
\hline Algeria & $7-22^{\mathrm{iv}}$ & 8 & 50 \\
\hline Egypt & none $^{\mathrm{ii}}$ & 0 & 80 \\
\hline Senegal & $5-21$ & 0,3 & 3 \\
\hline Ivory Coast & $28-36^{\mathrm{iv}}$ & 2 & 3 \\
\hline Ghana & $15-45^{\mathrm{iv}}$ & 1 & 3 \\
\hline Angola & $35-50^{\mathrm{iv}}$ & 6 & 7 \\
\hline Kenya & $30^{\text {iv }}$ & 3 & 4 \\
\hline Botswana & $17^{\mathrm{iv}}$ & 1 & 2 \\
\hline Saudi Arabia & none $\mathrm{e}^{\mathrm{ii}}$ & 0 & 150 \\
\hline Iran & $4-12^{\mathrm{iv}}$ & 22 & 220 \\
\hline Kazakhstan & none $^{\mathrm{ii}}$ & 0 & 100 \\
\hline Turkey & 21 & 60 & 120 \\
\hline Thailand & $20-25^{\mathrm{iv}}$ & 50 & 110 \\
\hline Malaysia & none $^{\mathrm{ii}}$ & 0 & 80 \\
\hline Pakistan & none $^{\mathrm{ii}}$ & 0 & 60 \\
\hline Bangladesh & 3,45 & 2 & 18 \\
\hline
\end{tabular}

Since Africa is poor, it does not use much energy like fossil fuels, except Maghreb as well as Egypt plus much polluting South Africa, which countries must make the energy transition as quickly as possible. The rest of Africa uses either wood coal, leading to deforestation, or water power. They can increase solar power without problems when helped financially. For a 


\section{Macrothink}

Journal of Social Science Studies

ISSN 2329-9150

2018, Vol. 5, No. 1

few Asian countries, the numbers are staggering, but can be fulfilled, if turned into the number ONE priority. Some of the poor nations need external financing and technical assistance.

\section{Conclusion}

We are not yet at the point of irreversibility, meaning there are still a few degrees of freedom for government policy-making and international governance. The plans of the UNFCCC must be implemented by all nations: Goal I: halting $\mathrm{CO} 2$ growth, Goal II: reducing $\mathrm{CO} 2 \mathrm{~s}$ until 2030 and Goal III: near complete decarbonisation by 2075. But time is certainly running out.

\section{References}

\section{SOURCES: Solar power}

Paris 2015: Tracking country climate pledges. Carbon Brief, https://www.carbonbrief.org/paris-2015-tracking-country-climate-pledges

EDGAR v 4.3.2, European Commission, Joint Research Centre (JRC)/PBL Netherlands Environmental Assessment Agency. Emission Database for Global Atmospheric Research (EDGAR), release version 4.3.2. http://edgar.jrc.ec.europe.eu, 2016 forthcoming

$\mathrm{CO} 2$ Emission Reduction With Solar

http://www.solarmango.com/in/tools/solar-carbon-emission-reduction

\section{GDP sources:}

World Bank national accounts data - data.worldbank.org

OECD National Accounts data files

\section{GHG and energy sources:}

World Resources Institute CAIT Climate Data Explorer - cait.wri.org

EU Joint Research Centre Emission Database for Global Atmospheric

Research - http://edgar.jrc.ec.europa.eu/overview.php

UN Framework Convention on Climate Change -

http://unfccc.int/ghg_data/ghg_data_unfccc/time_series_annex_i/items/3814.php

International Energy Agency. Paris.

Energy Information Administration. Washington, DC.

BP Energy Outlook 2016.

EU Emissions Database for Global Research EDGAR,

http://edgar.jrc.ec.europa.eu/

World Bank Data Indicators, data.worldbank.org

British Petroleum Statistical Review of World Energy 2016

\section{Literature}

Conka, K. (2015). Un Unfinished Foundation. The United Nations and Global Environmental Governance. Oxford: OUP. https://doi.org/10.1093/acprof:oso/9780190232856.001.0001

Kaya, Y., \& Yokoburi, K. (1997). Environment, energy, and economy: Strategies for sustainability. Tokyo: United Nations University Press.

Ostrom, E. (1990). Governing the Commons. Cambridge: Cambridge U.P. 
https://doi.org/10.1017/CBO9780511807763

Ramesh, J. (2015). Green Signals: Ecology, Growth and Democracy in India. Oxford: Oxford University Press. https://doi.org/10.1093/acprof:oso/9780199457526.001.0001

Sachs, J. D. (2015). The Age of Sustainable Development. New York: Columbia University Press. https://doi.org/10.7312/sach17314

Stern, N. (2007). The Economics of Climate Change. Oxford: OUP. https://doi.org/10.1017/CBO9780511817434

Stern, N. (2015). What are we waiting for? Cambridge, MA: MIT Press.

Vogler, J. (2016). Climate Change in World Politics. Basingstoke: MacmillanPalgrave. https://doi.org/10.1057/9781137273413

\section{Notes}

Note 1. The United States has pulled out of the deal

Note 2. No absolute target

Note 3. Pledge is above current level, no reduction

Note 4. Upper limit dependent on receiving financial support

\section{Copyright Disclaimer}

Copyright for this article is retained by the author(s), with first publication rights granted to the journal.

This is an open-access article distributed under the terms and conditions of the Creative Commons Attribution license (http://creativecommons.org/licenses/by/3.0/).

\footnotetext{
i The United States has pulled out of the deal

ii No absolute target

iii Pledge is above current level, no reduction

iv Upper limit dependent on receiving financial support
} 